\title{
Militarization and social development in the Third World
}

\author{
Julia Kwong* and Zachary Zimmer ${ }^{b}$ \\ - Department of Sociology \\ University of Manitoba \\ - Population Studies Center \\ University of Michigan
}

\section{Abstract}

In this study we integrated the development to suggest the ways whereby militarization can affect development. We examined the effects of three components of militarization highlighted in these theories on the social development of ninety-two developing countries. Overall, our findings support the dependency theory's emphasis on the detrimental impact of international trade on disadvantaged nations. There is a significant negative correlation between arms import and social development. Arms export and indigenous spending are correlated with social development in the expected directions but their beta coefficients are not significant. The diverse ways these three aspects of militarization have been shown to affect social development help to explain some of the conflicting findings in the literature and point to the need to study these variables in their disaggregated form.

The nations of the world are spending an inordinate amount on their military budgets. According to Sivard's World Military and Social Expenditures (1987), in 1984 the world's military budget was about US $\$ 769$ billion, $\$ 150$ billion of which came from the developing nations. This represented 5.6 per cent of the latter's GNP, surpassing their budgets for education and health which together made up only 5.1 per cent of this total. The military expenditure in these countries seems to be extraordinarily high, especially when the provision of health, education, and other social programs (and not arming the nation) are often their touted goals.

This investment in militarization would perhaps have been justified if there is strong evidence to show that militarization benefits development, but research findings on this issue are far from reassuring. Benoit's classic study $(1973,1978)$ found that countries with larger defense budgets displayed higher economic growth when controlling for investment and bilat- 
eral aid. Fredericksen and Looney $(1982,1983)$ came to a similar conclusion studying the better endowed developing nations. Deger and Sen (1983) argued that these results are exaggerated. Rosh (1986), Moon and Dixon (1986), and Biswas and Ram (1986) found no significant relationship between militarization and development. In direct contradiction to Benoit's finding, Faini et al. (1984) found a 0.13 per cent decrease in production rate accompanying every 10 per cent increase in defense spending. Lim's findings (1983) also confirmed this harmful effect of militarization on economic growth.

Given the contradictions between the spending realities and the articulated priorities among the Third World nations, and the controversial findings in the literature, interesting questions arise. Does military spending accelerate economic growth? Or do these expenditures divert valuable and rare resources from development? Or, to ask a more fundamental question: What effect does militarization have on development? The answer to this question is especially relevant given the political tensions, skirmishes and war generated by, among other things, the arms race among the Gulf states, and the starvation resulting in no small extent from internal and external strife facing the African nations.

\section{Two divergent theoretical frameworks}

This study seeks a theoretically informed approach to answer this question on the relationship between militarization and development in the Third World. Two theories which have influenced social scientists in the field of development are modernization and dependency. The assumptions associated with these theories are different, and lead to very different views of development; and consequently, militarization. These two theories will be used here as heuristic devices to highlight what divergent assumptions can bring to research on this topic. We shall attempt to reconcile the differences and develop an understanding on the effects of militarization and development.

Parsons' $(1966,1977)$ and Eisenstadt's (1966, 1987) modernization theories are sophisticated theoretical models. The treatment here will not do justice to their ideas, but serves to focus on their more basic tenets and to delineate the role militarization can play in development. Modernization theory posits that development is linear and the complex industrial societies in the West represent the model or ideal for the rest of the world. Development occurs when Third World countries abandon their particularistic, simple, and atomistic existence to follow in the footsteps of the West and adopt its complex social systems. The building of the nation state, industrialization, urbanization, and bureaucratization, and the concomitant values undergirding these institutions characterizing the West are hallmarks of modernization.

Militarization, which has almost always been based on the bureaucratic model and the transfer of technology from the West, necessarily represents progress. Moreover, its effects are not confined to one institution but spill over to others. Benoit $(1973,1978)$ argued that militarization provides the prerequisites of stability and security needed for economic growth. It pro- 
vides extensive training, fosters research and development, raises aggregate demand, utilizes idle resources, increases output, and promotes economic progress. Janowitz (1964), Levy (1971), and Pye (1968) focused on the broader social implications of militarization. They argued that the military is an agent of and catalyst for change with innovations introduced here being a conduit to introduce Western values - such as living and working by the clock, thriftiness, following instructions, etc. - necessary for modernization. The military breaks down traditional parochialism and builds a sense of nationhood. The technologies and know-how used in defense can be applied to other industries, and the organization and management skills associated with the military machinery may be adopted by other social organizations (Levy, 1971).

Again, we shall not be drawn into a discourse on the subtle variations among the dependency theorists or on their limitations (Brenner, 1977; Garst, 1985), but shall instead elaborate on their major propositions as they relate to our topic. Unlike modernization theorists who see social change in aggregate terms, such as a rise in GNP, increases in industrial output, and the creation of other infrastructures modelled on the West, they value the human aspect of development (Amin, 1976). To them, industrialization or increased GNP does not necessarily represent development; these changes are relevant only if they benefit the population. If the benefits are confined to the few or, in some cases, leave the country, only economic growth and not development has taken place. Education, housing, medical care, and other social programs and the sharing of these provisions are better yardsticks of development than economic growth.

Dependency theorists focus on the inequities in international relations and the negative impact integration into the world trade and political orders have brought to the developing world (Frank, 1969, 1973; Wallerstein, 1974, 1980, 1989; Kaldor, 1978). These unequal relations may not be entirely responsible for their backwardness, but they certainly condition, if not strangle, development in these nations (Cardoso and Faletto, 1979). In the unequal structures of exchange in international relations, the advanced or metropole countries dictate terms of trade and political or other social arrangements which benefit themselves but strangle or lead to disarticulated development in the developing or peripheral nations. Even when participation in the world economy brings immediate 'progress', the new infrastructural arrangements generally cater to the needs of the advanced foreign countries and not the indigenous ones. These changes may carry immediate and short-term benefits, but the elites and not the general populace are usually the beneficiaries. In the long run such 'progress' may even be detrimental to these countries.

Militarization is only one of the many factors impinging on a country's development, and dependency theorists seldom focus on its role in development. However one can extrapolate from their arguments to develop a picture of the role of militarization within this paradigm. Following their argument on disarticulated development, the dependency theorists would likely see militarization putting pressure on the scarce supplies of skilled workers and capital in these nations. New military installations divert re- 
sources from production to satisfy basic needs and much needed social programs. Even if militarization creates jobs and raises production rates, these programs are not necessarily the most appropriate for these nations at their stage of development. Consequently, the benefits from these military programs do not necessarily spread to other industries because these technologies may be too advanced to be useful to or absorbed by other industries. Furthermore, such installations may even bolster the political and economic power of an oppressive elite responsible for their country's peripheral status in the first place.

In addition, militarization, which often involves the import of arms, ties these countries to their suppliers and perpetuates their subservience in the international order. The manner in which this process occurs is best articulated by Albrecht et al. (1974) who argued that the colonialist era created an economic infrastructure whereby the Third World became dependent on the First World for, among other things, military goods. These arrangements have facilitated the expansion of the West and guaranteed the dependent positions of these developing nations; and the advanced nations are quick to suppress any attempts to loosen the bonds or change the status quo. This phenomenon constitutes underdevelopment, that is, these nations are not given the opportunity to develop their potential.

\section{Reconciliation and focus of the study}

It is obvious from the above discussion that these two paradigms have very different views of militarization and development. The modernization paradigm focuses on the indigenous military infrastructures within the developing countries, whereas the dependency approach emphasizes military imports and the disarticulated development represented and brought about by military programs. To the modernization theorists development is primarily reflected in the country's aggregate economic and other material performances, whereas the dependency theorists view it as social progress to be shared by the population. Their different emphases, however, are not contradictory - they only represent different dimensions of the same two concepts. Indigenous installations and endogenous spending are the Janus face of militarization, and economic progress and social services are both integral components of development.

As a consequence of their different foci, the two paradigms of development have very different ideas as to how militarization can shape development. Nevertheless the paths they envisage as to how the former impinges on the latter are not mutually exclusive. On the contrary, as we shall see below, these can be readily integrated to provide a useful and comprehensive framework to capture the complicated relations between these two complex social phenomena.

In their optimism, modernization theorists have examined the positive effects of military expenditures spent inside a country, overlooking the possibility that such investments may go abroad. The dependency theorists' emphasis on the global economy exposes this oversight. Military expenditures are not necessarily expended at home, but can be used to import arms 
from abroad. This suggests that military programs can be examined in at least two respects - the expenditures devoted to the internal military infrastructure and that on military imports.

Furthermore, dependency theorists have alluded to not only the losses brought about by arms import but the benefits accrued to the advanced nations supplying them. Following the logic of this argument, developing countries exporting arms should also benefit; and dependency theorists, like Luckham (1978), are sensitive to the presence and potential advantages of such arms export. Therefore, the export of arms is a third dimension of militarization to be considered.

There are of course other aspects to this complex phenomenon of militarization. The build-up of arms can be used for defensive or offensive purposes, and this specific military goal can shape the size of the military budget, the strength of the armed forces and other supporting personnel, the organization of the military complex, and the types and quantities of weaponry. There are also related aspects of militarization, such as, the military control of the state and the amount of military aid. We do not wish to dwell on these more complex and technical aspects. Instead we shall follow only the arguments in the modernization-dependency debate and concentrate on the above-mentioned three aspects of militarization - military installations at home, military spending abroad, and the value of arms export. Furthermore, for the sake of simplicity and quantification, we shall represent the complexities of military installations by the military budget expended at home.'

Development is as complex, if not a more complicated concept than militarization. Again, the modernization-dependency debate shows quite clearly that development can incorporate both economic and social dimensions. For a start, we shall concentrate in this study on only one of these dimensions. Most existing studies on militarization and development, however, were carried out by economists and political scientists who used GNP or its growth rate as the indicators of development often to the neglect of the social aspect. ${ }^{2}$ This analysis compensates for this omission by adopting an index of development supported by the International Peace Research Association (1978) which deals exclusively with basic human needs. This index only includes three items: infant mortality, life expectancy, and literacy; but these indicators are more comprehensive than their number suggests. They measure not so much the social services the country provides, but the effectiveness of these programs which is the ultimate goal of development. The exclusive use of social indicators to measure this often ignored but vital aspect of development will bias our measure towards the dependency approach.

Decomposing militarization into its three components allows us to easily delineate the ways in which the former can affect social development. Following the arguments of the dependency approach, militarization creates or perpetuates underdevelopment when a country imports arms. Valuable foreign exchange is drained from the nation, and capital investment for the other industrial and social programs suffer. Arms import therefore should undermine social development. On the other hand, a nation will benefit if it 
is an exporter of arms. Arms export has enriched the developed nations and allowed them to maintain their dominance in the world economy; and therefore developing nations engaged in these activities should also reap such benefits. Since the outflow of foreign exchange which usually characterizes the Third World has been reversed in this situation, the cash inflow should provide the capital for other industrial investments and social programs.

Whether the creation of an indigenous military industrial structure will benefit development is more controversial. Modernization theorists have argued that militarization generates employment and material wealth for the nations. There may also be spillover effects to other social institutions which accelerate these countries' overall development. The dependency theorists do not deny that this is possible, but think that these benefits are limited because most of these countries do not have the infrastructural prerequisites to take full advantage of these opportunities. Even if military programs provide immediate employment, there is usually a time lag before the social benefits are felt. Furthermore, such diversions of resources to military investment may even hurt their economic and social programs.

Both the modernization and dependency theorists agree that militarization can bring positive consequences, but the dependency theorists are more skeptical. They take note of the possible negative effects, and argue that the prevalence of the positive ones is contingent to a large extent on the state of readiness of the Third World countries to take advantage of them. Given the low level of development in these nations, it is likely the negative consequences may cancel out the positive ones, making any correlation between internal militarization and development a tenuous and possibly a negative one.

These considerations convince us that the relevant research question in the study of militarization and development is no longer whether the former has a positive or negative impact on the latter. A more fruitful approach is to ascertain how the different components of militarization shape the different dimensions of development. The following is a step in this direction, albeit a limited one. Following the pointers in the two development paradigms, the analysis will concentrate only on three facets of militarization. We hypothesize that a military program that depends upon imports will drain the nation's wealth and hurt social development, whereas one with a strong nilitary industrial base which allows the country to sell arms will bring benefits to the nation. Furthermore, we hypothesize that the creation and maintenance of an indigenous military infrastructure will have a less significant impact on social development.

\section{The data set}

The best way to test our hypotheses would be to carry out a multinational and longitudinal study over an extended period of time, and the information further embellished by case studies. The pursuit of such methodological rigour, however, has to be compromised with the availability of quality data and the limitations imposed by a paper of this length. We settled for a cross-sectional analysis while fully recognizing its limitations, the advantages 
of the longitudinal approach (Tuma and Hannan, 1984: 12-14), and the richness of data coming from case analysis. We carried out regression analysis on the data collected on ninety-two nations in 1982 because information on militarization and social development for these countries in this year is most complete.

Military programs are susceptible to changes in international and national politics. However, an examination of Facts on File shows that no 'traumatic' occurrences took place in the early 1980 s to dramatically change the world balance of power or to make 1982 any more unique than other years in the recent period. The situation in the Middle East, and especially in Lebanon, has always been volatile. The OPEC countries were negotiating to reduce their oil output but the rich oil-producing Arab countries were excluded in our sample. The major political development in 1981-82 was the growing challenge of the Solidarity movement to the Polish government, but neither Poland nor other members of the Eastern European bloc nations are among the countries being studied here.

Multinational analysis does not facilitate studying the situation of each nation specifically, but we did attempt to take into account the different political contexts of the nations selected. Political scientists have shown that military spending is affected by the political alignment of countries to the Eastern or Western bloc, their involvement in internal strife or external war, the nature of the government (whether democratic/autocratic, civilian/military) and the presence of the military base (Looney, 1988, 1990; Maizels and Nissanke, 1986; Rosh, 1988). The scope of this paper will not allow us to explore the role of all these factors; instead we controlled for their influences by including seven dichotomous variables measuring these situations in our regression model. These are: threat or involvement in external wars, source of arms supplies, offensive or defensive nature of the military, internal strife, political alignment with Eastern or Western bloc, the presence of foreign military bases, and the nature of the government.

In choosing countries for our sample, we use the criterion established by the World Bank and select only those with less than a GNP of US $\$ 7075$ per capita in 1982. This limit excludes nations with high incomes, such as the oil-exporting Arab countries which constitute a unique category of their own. According to the data provided in Sivard's Military and Social Expenditure 1985, 110 nations should have been included, but eighteen countries are eliminated due to inadequate information. Still, this list is one of the largest number of cases included in a study of this nature (see appendix). Other data needed for the analysis comes from the United States Arms Control and Development Agency Report, World Military Expenditures and Arms Transfer (1986), Ruth Sivard's Military and Social Expenditures (1985), and Kidron and Smith's The War Atlas (1983). ${ }^{3}$

The three items used to create our dependent variable - infant mortality, literacy rate, and life expectancy - were subjected to a principal component factor analysis. As we expected, all three items loaded highly on to only one factor. To create the social development index, we standardized and then weighted each item according to its explanatory power, using the 
derived function coefficients. The resultant index has a mean of 0 and a maximum score of +3 . A negative score indicates a low level of development, and a positive score a high level of development amongst our sample.

Both arms imports and exports are measured as a proportion of the country's total imports or exports. These measures, standardized by the values of the total import or export, allow for better comparison across nations. Furthermore, the percentage of arms import also reflects the amount of resources leaving the nations in order to get military goods as opposed to other imports which may have a more beneficial impact on the nation. Similarly, arms export as a percentage of the total exports provides indications of the size of the arms export industry as opposed to other export-oriented industrial activities.

The mean arms import in our sample is 6.3 per cent with a standard deviation of 11.6 per cent. Twenty-seven nations, or 29 per cent in our sample, did not import arms in 1982; but the arms import of Syria and Afghanistan valued close to 58 per cent of their total import. This high figure in arms import in Syria stems from her involvement in the Israel-Lebanon conflict, and the situation in Afghanistan was volatile with its president ousted, the Soviets occupying the country, and continuing factional fights.

Only fifteen of the ninety-two countries exported arms in 1982, and among them, only six countries had arms exports worth more than 1 per cent of its total exports. Consequently, the mean score for arms export is only 0.4 per cent with a standard deviation of 1.6. This low mean score and small standard deviation for this variable may affect the correlation coefficient and as we shall see later, attenuate the effects of arms export on development.

Indigenous militarization is measured as the portion of military expenditures spent only inside the country and standardized by the size of the population. We did not standardize military expenditure by GNP as other studies have done because we have included the latter as an independent variable. Instead we use per capita which measures the size of the military burden on each member of the population. The nations in the sample spent an average of $\$ 54$ per capita on indigenous militarization in 1982 with a range of $\$ 1$ to $\$ 1155$.

Gross national product, which has often been used as an indicator of development, is used here as a control. To do this is not to deny the influence militarization may have on GNP or economic development, but to recognize the reciprocity of this relationship. A cursory examination of the data reveals a strong correlation between the two variables. Countries with over $\$ 1500$ GNP per capita spent an average of $\$ 205$ per person on total military expenditures and have a mean development score of +0.97 . On the other hand, countries with less than $\$ 400$ GNP per capita spent only an average of $\$ 9$ per person on this item, and have a development score of -0.88 . Indeed these crude correlations provide support to the modernization theorists' position that militarization affects economic and social development positively. The same data, however, can be interpreted as indicative of the ability of the 
richer countries to have more expensive military and also social programs. Treating GNP together with the seven variables mentioned earlier as extraneous allows us to factor out their effects and to examine more closely the influence of militarization on social development.

\section{Findings}

As a first step in our analysis, we inspected the zero-order correlations between the exogenous variables and the three indicators of militarization. These results are shown in Table 1 . Indigenous spending per capita is positively correlated with GNP, orientation of the military, and war. Arms import is positively associated with military orientation, internal strife, war, and the existence of foreign military bases; but is negatively correlated with the type of the regime and alignment. Finally, arms export is positively correlated with GNP, the supplier, and the existence of foreign military bases, and negatively correlated with military orientation. The theoretical explanation for these results is too complicated to be elaborated here; suffice to say that they overlap with findings in the literature. These results, showing the three dimensions of militarization being shaped by very different factors, further suggest that these indicators represent different activities that should be examined separately. More importantly, all the exogenous variables are significantly correlated to at least one of the militarization indicators justifying their incorporation as controls.

Table 1: Zero-order coefficients between exogenous variables and indicators of militarization.

\begin{tabular}{|c|c|c|c|}
\hline & $\begin{array}{c}\text { Arms } \\
\text { Imports }\end{array}$ & $\begin{array}{c}\text { Indigenous } \\
\text { Militarization }\end{array}$ & $\begin{array}{c}\text { Arms } \\
\text { Exports }\end{array}$ \\
\hline \multicolumn{4}{|l|}{ Exogenous Variables } \\
\hline GNP per capita & -.09 & $.57^{*}$ & $.20^{*}$ \\
\hline $\begin{array}{l}\text { Military orientation } \\
\qquad(1=\text { offensive, } 0=\text { Other })\end{array}$ & $.23^{*}$ & $.27^{*}$ & $-.28^{*}$ \\
\hline $\begin{array}{l}\text { Internal strife } \\
\qquad(1=\mathrm{Yes}, 0=\mathrm{No})\end{array}$ & $.19^{*}$ & .13 & .03 \\
\hline $\begin{array}{l}\text { Nature of governance } \\
\qquad(1=\text { Parliamentary, } 0=\text { Other })\end{array}$ & $-.24^{*}$ & .10 & .16 \\
\hline $\begin{array}{l}\text { War } \\
\qquad(1=\mathrm{Yes}, 0=\mathrm{No})\end{array}$ & $.41^{*}$ & $.21^{*}$ & .07 \\
\hline $\begin{array}{l}\text { Arms supplier } \\
\quad(1=\text { Western nation, } 0=\text { Other })\end{array}$ & -.15 & .06 & $.17^{*}$ \\
\hline $\begin{array}{l}\text { Alignment } \\
\qquad(1=\text { Western, } 0=\text { Other })\end{array}$ & $.49 *$ & -.12 & -.00 \\
\hline $\begin{array}{l}\text { Foreign bases } \\
\qquad\left(1=\text { Yes, } 0=N_{0}\right)\end{array}$ & .24 & -.01 & $.22^{*}$ \\
\hline
\end{tabular}

Table 2 displays the simple bivariate relationships between the three aspects of militarization and social development, and their zero-order correla- 
tions. The bivariate tables provide a description of the data. Arms imports, exports, and indigenous militarization are trichotomized to provide maximum homogeneity within groups while maintaining more or less comparable numbers, and their mean social development scores are provided for comparison.

Table 2: Average score on the social development scale by the level of arms imports, indigenous militarization and arms exports and zero-order correlations.

\begin{tabular}{lcc}
\hline Arms imports & $N$ & Average social development score ${ }^{*}$ \\
\hline High importers (5\% and over) & 30 & -.18 \\
Low importers (below 5\%) & 34 & +.14 \\
Non importers & 27 & +.07 \\
zero-order correlation & & $-.22(\mathrm{p}<0.05)$ \\
\hline
\end{tabular}

* difference are not significant at a .05 level

* data for Guinea is not complete and is excluded here

\begin{tabular}{lll} 
Indigenous militarization & $N$ & $\begin{array}{l}\text { Average social } \\
\text { development score }\end{array}$ \\
\hline Highest spenders $(\$ 30+)$ & 31 & +.57 \\
Middle spenders $(\$ 10-\$ 30)$ & 28 & +.06 \\
Lowest spenders (below $\$ 10)$ & 33 & -.59 \\
zero-order correlation & & $+.26(\mathrm{p}<0.05)$
\end{tabular}

* differences are significant at a .05 level

\begin{tabular}{lcc} 
Arms exports & $N$ & $\begin{array}{l}\text { Average social } \\
\text { development score }\end{array}$ \\
\hline High exporters (1\% and over) & 6 & +.72 \\
Low exporters (below 1\%) & 9 & +.48 \\
Non exporters & 77 & -.11 \\
zero-order correlation & & $+.15(p>0.0 .5)$
\end{tabular}

"difference between non-exporters and exporters (high and low exporters combined) arc significant at a 0.05 level.

The first sub-table in Table 2 shows a significant negative correlation between arms import and social development, showing that increasing arms imports is related to lower levels of development. The impression is confirmed to some extent by comparing the mean scores on social development among the three groups of nations divided on their involvement in arms import. It is however interesting to note that among the three groups of nations, the middle importer group scores highest on the development scale.

The results in the second bivariate table show a significant positive correlation between indigenous militarization and development. Countries that spend over $\$ 30$ per capita on military programs have a development score of +0.57 compared with a -0.59 score for the third group spending less than $\$ 10$ per capita on that item.

In the third bivariate table, countries that do not export arms have a development score of -0.11 whereas those that do so have the respective scores 
of +0.48 and +0.72 , with the high exporters having the highest development score. The trichotomised results show that arms exports affect development in the expected direction, and the results are significant when the development scores of the exporter nations are compared with those of the non-exporters. The insignificant zero-order correlation coefficient between these two variables is perhaps affected by the small deviations in the export variable noted earlier.

To examine the complex relations between militarization and social development more closely, a multivariate ordinary least squares regression procedure was employed. The results which can be seen in Table 3 depict the effects of all eight exogenous variables and the three dimensions of militarization on social development. Together, the model explains 52 per cent of the variance in development.

Table 3: Results of ordinary least squares regression with social development as the dependent variable

\begin{tabular}{lcccc}
\hline & $B$ & $\begin{array}{c}\text { Standardized } \\
\text { Beta }\end{array}$ & $T$ & Sig. T \\
\hline $\begin{array}{l}\text { Independent variable } \\
1 \text { Indigenous } \\
\quad \text { militarization }\end{array}$ & $-8.80 \mathrm{E}-04$ & -.13 & -1.09 & .28 \\
2 Arms imports & -.02 & -.25 & -2.33 & .02 \\
3 Arms exports & +.07 & +.11 & +1.09 & .28 \\
4 GNP & $+4.20 \mathrm{E}-04$ & +.58 & +5.37 & .00 \\
5 War & +.32 & +.16 & +1.58 & .12 \\
6 Major arms supplier & -.20 & -.10 & -1.11 & .27 \\
7 Nature of the military & +.05 & +.03 & +.31 & .76 \\
8 Existence of internal & +.20 & +.10 & +1.14 & .26 \\
strife & & & & \\
9 Alignment & +.06 & +.02 & +.21 & .83 \\
10 Housing foreign & +.16 & +.07 & +.84 & .40 \\
$\quad$ military bases & & & & \\
11 Nature of the & & & & \\
$\quad$ government & +.48 & +.24 & +2.61 & .01 \\
R-square = .52 & & & & \\
\hline
\end{tabular}

Among the eight control variables, only GNP and the nature of governance have any significant influence on social development. The former has a standardized beta coefficient of +0.58 and the latter +0.24 . These results are similar to findings in the literature which suggest that social development is contingent on the available economic resources and is mediated by the nature of the government's responsiveness to popular demands (Looney 1988, 1990). As for the effects of militarization, only arms import has a significant negative correlation of -0.25 with the index of social development. The two beta coefficients between indigenous militarization and arms export on one hand and social development on the other are insignificant at the 0.05 level. 
The relationship between arms import and development is clear. The results of both the bivariate and regression analyses suggest a negative correlation supporting the dependency theorists' position that the greater tie of the developing nations to the global military economy is detrimental. Our empirical data do not provide information as to how these military imports can be harmful, but neither do they disprove the dependency theorists' argument that arms import can hurt social development in more ways than one. Importing arms means the outflow of material resources, a cut in the budget for social programs, and undermining the population's well-being. The military input may embody advanced technology, but if a nation is not capable of producing these arms, it is also not likely to be able to incorporate these advanced technologies in industrial use in the immediate future. Moreover, buying military equipment means a divestment of resources from industries which can generate income - a necessary prerequisite to the provision of social services.

Despite the consistent results in the bivariate table and the regression analysis, the curvilinear relationship between arms import and social development in Table 2 needs to be explained. The curvilinear relationship displayed in the trichotomized bivariate table may be a function of the level of economic development in these three groups of countries and the value of their arms import as a proportion of their import trade. In our sample, the non-importers have slightly lower per capita GNPs than countries importing some arms, and this perhaps accounts for their lower development score. The high importers spent an average of 17 per cent of their import budgets on this item with some nations spending as much as 30-50 per cent. Tying such high proportions of their resources to arms import prevents them from bringing in more 'useful' or income-generating commodities as well as diverting resources from other industrial investments and social programs. As a result, the middle category of arms-importing countries has higher development scores than those who import more arms and those who import less.

Indigenous militarization is positively correlated with social development in the bivariate table, but the relationship becomes insignificant once the control variables are introduced in the regression analysis. These contradictory findings can again be explained by the level of economic development of a country, which makes the observations of the relationship between indigenous militarization and social development in the simple bivariate table spurious. Recall that GNP is significantly correlated with indigenous militarization in Table 1 and that it is also significantly correlated with social development in the regression analysis. That is, a country with a higher GNP can afford a larger military budget, as well as better and more comprehensive education and health care programs than an economically lessendowed country. Consequently, countries with high per capita expenditures on indigenous militarization also have better records on social development. Hence, once the effects of GNP are controlled, the relationship disappears.

More importantly, these disparate results support the tenuous empirical relationship between indigenous militarization and social development that we have hypothesized and also suggest a complex interplay between the vari- 
ables. Unlike military imports which primarily affect a country's economic resources, indigenous military spending affects installations embedded in a nation. These military installations, as the modernization theorists have so eloquently described them, involve a constellation of economic, social, and cultural organizations which directly impinge on every aspect of the society.

Even in the area of social development alone, this relationship is a complex one. Indigenous militarization may produce material benefits in terms of employment and other economic spin-offs. These can be used for social services. The diffusion of Western values with their higher standards for satisfying human needs may generate a demand for social services; and a more efficient bureaucratic structure often associated with the military may provide for a more effective distribution of social services. On the other hand, military expenditure, even when used at home, can compete with social programs for scarce resources. That is, the opportunity costs of indigenous militarization are high and can outweigh the benefits. Even though indigenous militarization can bring economic expansion and resources necessary to finance social programs, these resources may not be put to such uses. Even if they are, these processes take time. Moreover, the demands for better social services may come only from military personnel and the benefits may be confined to that circle. These multifarious and sometimes contradictory ways whereby indigenous militarization can affect social development, and their delayed effects, explain why the relationship is insignificant here. Given the low level of development in these countries and the lack of preparedness to benefit from the positive effects of militarization, it should also not be surprising that the direction of the relationship between the two variables tends to be a negative one. These considerations call for further specifications of indigenous militarization in future analysis.

We have already alluded to the methodological explanation for the lack of a significant relationship between arms export and social development. Only fifteen countries are exporting arms. They are the third tier arms-production countries (Krause, 1992), and their products are much less sophisticated than those from the First World, their technology and many parts imported, their volume of production small. The volume and values of their military exports are low in comparison to their other exports. Arms exports constitute only a little more than 1 per cent of their total export even in the highest category of exporter nations in our sample. Since some of the parts needed for the manufacture of these exports have been imported (Krause, 1992; Ball, 1991), this layout cost attenuates the positive effects of income so gained. Furthermore, the defense industry is an integral part of the indigenous military infrastructure, and its effects as discussed earlier, and which we shall not repeat here, are mixed.

Military installations geared for arms export, however, have one decided advantage over the other indigenous military infrastructures per se - they earn much needed foreign exchange which can subsidize military production for home use or social programs. Consequently, military export does have a consistently postive effect on social development. There is evidence of a possible positive correlation in the bivariate analysis and also a weak positive 
coefficient in the regression results. The consistent ways whereby arms export affects social development in the simple bivariate and the regression analyses do suggest that developing countries manufacturing arms for export may reap some benefits from these activities. ${ }^{4}$

Finally, as a cautionary note we recognize that countries develop and global geo-political circumstances change. For example, the GNPs of Israel and Singapore have improved in the last decade to call to question their inclusion in our Third World country list. In addition, traumatic changes have also occurred in the Eastern European countries to change the balance of power in world politics and invalidate our dichotomy of countries into those aligned to the Eastern and Western blocs. These global changes affect the countries' arms installations and their abilities to import, manufacture, or export arms; and will alter somewhat the organization of these countries in our data set should an analysis be done in the nineties. Even though we are optimistic that our results will hold, whether these changes will produce fundamentally different results in the association between militarization and development remain a question. Only furure analyses which examine our propositions using longitudinal data, however, will give a more definitive answer as to whether the model developed here can withstand geo-political changes over time.

\section{Discussion and conclusion}

The relationship between militarization and development is a complex one. This study has focused only on the three dimensions of militarization highlighted in the modernization and dependency theories, and exclusively on their effects on social development. Even within this narrow confine, each component of militarization is found to relate to social development in its own unique way. Arms import and indigenous militarization are negatively correlated with social development, and arms export is positively correlated with it. While arms import and indigenous militarization affect social development in the same way, only the first relationship is significant at the 0.05 level. But in all these cases, the results are in the anticipated directions. The integrative theoretical approach utilized for the analysis, which takes into consideration the complex ways whereby the different components of militarization can affect development, helps to explain the different influences of militarization on social development.

Our findings and their theoretical explanations provide clues to both the absence of any significant correlations and the sometimes contradictory findings in the literature. Militarization and development are complex phenomena incorporating different dimensions. The different aspects of militarization do not act on development in the same way, and positive and negative effects can cancel each other out to produce seemingly insignificant results. Moreover, emphasis on one or the other dimensions of these concepts can yield very different results. As Ball (1988: 126) has shown in some detail, the choice and definition of militarization and development have contributed to discrepancies in findings. She has further pointed out that the 
ways in which these dimensions have been operationalized, the source of the data, the characteristics of the sampled countries, and the particular time period chosen, can further compound the problem. These cautionary methodological warnings aside, our study alerts us to the usefulness of a theoretically informed approach, and the importance of decomposing militarization and development into their constituents in order to understand their inter-relations.

We have tried to integrate the modernization and the dependency theories to sort out the influences of militarization on development; but as far as social development is concerned, the results lend greater credence to the latter than the former. Like the dependency theorists, we have to conclude that arms imports hurts social development, the creation of an indigenous military infrastructure does not necessarily benefit a nation, and that a nation is likely to gain from these programs when its military complex is capable of producing arms for sale to other countries. This last finding supports the dependency theory; and conversely also the modernization theory specifying the condition whereby militarization can be beneficial.

A core-periphery hierarchy exists even within the ranks of the developing countries. As in the larger world economy, the core countries in the developing world are better endowed, have higher GNPs per capita, a more sophisticated industrial infrastructure, and higher levels of social development than the peripheral nations without such capabilities. While these countries sell arms, the poorer nations import them, and the wealthier nations increase their income with monies from their less fortunate clients. The latter have used their hard-earned and highly-valued foreign exchange for armaments instead of machinery, other wealth-generating imports, or social programs. These arms-exporting nations in the developing world certainly would not have as strong a hold on their clients as their First World counterparts. Even wirhin the microcosm of core-periphery relationships among the developing nations, the stronger ones still stand to benefit at the expense of the weaker ones.

Just as the dependency theorists' highlighting of inequities in world politics does not imply that developing nations should break out of their dependency by pursuing autarkic development or following the examples of the First World in exploiting their disadvantaged neighbours, our conclusion should not be interpreted as the authors' condoning or encouraging the sale of arms among the developing nations as a means to improve their condition. It is simply an objective reality that one should be aware of. Given the lack of resources in these countries, few among them would have the capabilities to manufacture their own weaponry let alone produce arms for export, and they are more likely to buy than to sell arms. Since this is the case, there is only one logical conclusion - increased militarization among the developing nations will damage their social development. 


\section{Appendix}

\section{Countries in the analysis}

Afghanistan - Algeria - Argentina - Bangladesh - Barbados - Benin - Bolivia - Botswana - Brazil • Burkina Faso • Burma • Burundi - Cameroon • Central African Republic - Chad - Chile - Colombia - Congo - Costa Rica - Cuba • Cyprus • Dominican Republic • Ecuador • Egypt • El Salvador • Ethiopia $\bullet$ Fiji $\bullet$ Gabon $\bullet$ Gambia $\bullet$ Ghana $\bullet$ Guatemala $\bullet$ Guinea $\bullet$ Guyana - Haiti • Honduras • India • Indonesia • Iran • Iraq • Israel • Ivory Coast • Jamaica • Jordan $\bullet$ Kenya $\bullet$ South Korea $\bullet$ Lebanon - Lesotho • Liberia • Madagascar - Malawi $\bullet$ Malysia - Mali $\bullet$ Malta $\bullet$ Mauritania - Mauritius

- Mexico - Morocco - Mozambique $\bullet$ Nepal $\bullet$ Nicaragua $\cdot$ Niger $\bullet$ Nigeria - Pakistan - Panama - Papua New Guinea - Paraguay - Peru • Phillipines • Rwanda $\bullet$ Senegal $\bullet$ Sierre Leone $\bullet$ Singapore $\bullet$ Somalia $\bullet$ South Africa $\bullet$ Sri Lanka - Sudan - Swaziland $\bullet$ Syria - Tanzania $\bullet$ Thailand $\bullet$ Togo $\bullet$ Trinidad + Tobago $\bullet$ Tunisia $\cdot$ Turkey $\bullet$ Uganda $\cdot$ Uruguay $\bullet$ Venezuela $\bullet$ Yemen (Aden) $\bullet$ Yemen (Sana) $\bullet$ Zaire $\bullet$ Zambia $\bullet$ Zimbabwe

\section{Notes}

* We are grateful to Professor S. S. Halli and the anonymous reviewers for their comments on an earlier draft.

1 We acknowledge the drawbacks of reducing information on complex structures to simple coefficients, but this is a necessary compromise one has to make in statistical analysis. Also refer to note 3 for a more detailed discussion of the methodological issues.

2 Examples of exceptions are the works by Moon and Dixon (1986), and Sharda (1988).

3 International organizations may have standard definitions of national military expenditures, arms imports or exports, and other social indicators, but the different accounting systems of nations supplying the information affect the validity and reliability of the data and its comparability. Furthermore, it is difficult to disaggregate components of military expenditures, arms imports and exports, some of which may overlap. For example, military imports included in the nation's military budget may be used to manufacture arms for export (Krause, 1992). For further discussions on these methodological issues, see Sivard's (1985) section 'Notes on Data', Chan (1991), Laurance's (1992) section on 'Conceptualization and Measurement,' and United States Arms Control and Development Agency (1986). For a more detailed discussion of our data set, see Zimmer (1988), pp. 121-124.

4 Arms trade, and hence the volume of arms export, is sensitive to international politics. The volume of such trade for these third-tier arms production countries rose in the mid-eighties with the regional conflicts in the Middle East, and dropped in the late eighties. Furthermore, the disintegration of the Soviet Union and the political changes in the Eastern European bloc have introduced eager competitors to the trade, making it more difficult to maintain let alone to join the military export industry. Nevertheless, these fluctuations of the market should not affect our basic tentative conclusion - arms export benefits the exporting countries. 


\section{References}

Albrecht, U., D. Ernst, P. Lock and H. Wulf (1974), 'Armaments and Underdevelopment', Bulletin of Peace Proposals, 5, 173-85.

Amin, S. (1976), Unequal Development, New York, Monthly Review Press.

Ball, Nicole (1988), Security and Economy in the Third World, Princeton, Princeton University Press.

Ball, Nicole (1991), 'The Political Economy of Defense Industrialization in the Third World', in Andrew L. Ross, The Political Economy of Defense, New York, Greenwood, 175-201.

Benoit, E. (1978), 'Growth Effects of Defense in Developing Countries', International Development Review, 1, 14, 2-10.

Benoit, E. (1973), Defense and Economic Growth in Developing Countries, Lexington Ma., Lexington Books.

Biswas, B. and R. Ram (1986), 'Military Expenditures and Economic Growth in Less Developed Countries: An Augmented Model and Further Analysis', Economic Development and Cultural Change, 34, 361-72.

Brenner, Robert (1977), 'The Origin of Capitalist Development: A Critique of Neosmithian Marxism', New Left Review, 104, $25-93$.

Brzoska, Michael and Thomas Ohlson (1987), Arms Transfer to the Third World 1971-85, Oxford, Oxford University Press.

Cardoso, Fernando Henrique and Enzo Faletto (1979), Dependency and Development in Latin America, Berkeley, University of California Press.

Chan, Steve (1991), 'The Political Economy of Military Spending and Economic Performance: Directions for Future Research', in Andrew L. Ross, The Political Economy of Defense, New York, Greenwood Press, 203-222.

Dabelko, D. and J.M. McCormick (1977), 'Opportunity Costs of Defense: Some Cross-National Evidence', Journal of Peace Research, 14, 145-54.

Deger S. (1986), 'Economic Development and Defense Expenditure', Economic Development and Cultural Change, 35, 179-96.

Deger, S. and S. Sen (1983), 'Military Expenditures, Spin-off and Economic Development', Journal of Development Economics, 13, 1-2, 67-83.

Eisenstadt, S.N. (1966), Modernization: Protest and Change, Englewood Cliffs, Prentice Hall.

Eisenstadt, S.N. (1987), Pattcrns of Modernity', Washington Square, New York University Press.

Facts on File 1981, (1982), New York, Facts on File Inc.

Facts on File 1982, (1983), New York, Facts on File Inc.

Faini, R., P. Arnez and L. Taylor (1984), 'Defense Spending, Economic Structure and Growth: Evidence Among Countries Over Time', Economic Development and Cultural Change, 32, 487-98.

Frank, A.G. (1973), 'The Development of Underdevelopment', in C.K. Wilber (ed.), The Political Economy of Development and Underdevelopment, New York, Random House, 109-120.

Frank, A.G. (1969), Capitalism and Underdevelopment in Latin America, New York, Monthly Review Press.

Fredriksen, P.C. and R.E. Looney (1983), 'Defense Expenditures and Economic Growth in Developing Countries', Armed Forces and Society, 9, 633-45.

Fredriksen, P.C. and R.E. Looney (1982), 'Defense Expenditures and Economic Growth in Developing Countries: Some Further Empirical Evidence', Journal of Economic Development, 7, 113-25.

Garst, Daniel (1985), 'Wallerstein and his Critiques', Theory and Society, 14, 469-495.

International Peace Research Association (1978), 'The Impact of Militarization on Development and Human Rights', Bulletin of Peace Proposals, 7, 170.

Janowitz, M. (1964), The New Military: Changing Patterns of Organization, New York, Russell Sage. 
Kaldor, M. (1978), 'The Military in Third World Development', in R. Jolly (ed.), Disarmament and World Development, Oxford, Pergamon Press, 57-82.

Kennedy, G. (1974), The Military in the Third World, London, Duckworth.

Kidron, M. and D. Smith (1983), The War Atlas, London, Pan Books.

Krause, Keith (1992), Arms and the State: Patterns of Military Production and Trade, Cambridge, Cambridge University Press.

Laurance, Edward J. (1992), The International Arms Trade, New York, Lexington.

Levy, M.J. (1971), 'Armed Force Organization', in H. Bienen (ed.), The Military and Modernization, Chicago, Aldine Atherton, 41-78.

Lim, D. (1983), 'Another Look at Growth and Defense in Less Developed Countries', Economic Development and Cultural Change, 31, 377-84.

Looney, Robert E. (1988), 'The Political Economy of Third World Military Expenditures: Impact of Regime Type on the Defense Allocation Process', Journal of Political and Military Sociology, 16, 1, 21-30.

Looney, Robert E. (1990), 'Militarization, Military Regime and the General Quality of Life in the Third World', Armed Forces and Society, 17, 127-139.

Luckham, R. (1978), 'Militarization and International Dependence', in R. Jolly (ed.), Disarmament and World Development, Oxford, Pergamon Press, 35-56.

Maizels, A. and M.K. Nissanke (1986), 'The Determinants of Military Expenditures in Developing Countries', World Development, 14, 1125-40.

Moon, Bruce E. (1991), The Political Economy of Basic Human Needs, Ithaca, N.Y., Cornell University Press.

Moon, B.E. and W. Dixon (1986), 'The Military Burden and Basic Human Needs', Journal of Conflict Resolution, 30, 660-684.

Nabe O. (1983), 'Military Expenditures and Industrialization in Africa', Journal of Economic Issues, 17, 575-87.

Parsons, Talcott (1966), Societies: Evolutionary and Comparative Perspectives, Englewood Cliffs, Prentice Hall.

Parsons, Talcott (1977), The Evolution of Socicties, Englewood Cliffs, Prentice Hall.

Pye, L.W. (1968), 'Armies in the Process of Political Modernization', in J.L. Finkle and R.W. Gable, Political Development and Social Change, New York, John Wiley and Sons, 379-85.

Rosh, R.M. (1986), 'The Inpact of Third World Defense Burdens on Basic Human Needs', Policy Studies Journal, 15, 135-46.

Rosh, R.M. (1988), 'Third World Militarization: Security Webs and the States They Ensnare', Journal of Conflict Resolution, 32, 671-698.

Rothschild, K.W. (1973), 'Military Expenditure, Exports and Growth', Kyklos, 804-13.

Sharda, B.D. (1988), 'Third World Militarization and Income Inequality', International Journal of Contemporary Sociology, 25, 141-53.

Sivard, R.L. (1987), World Military and Social Expenditures, Washington, World Priorities.

Sivard, R.L. (1985), World Military and Social Expenditures, Washington, World Priorities.

Tuma, Nancy Brandon and Michael T. Hannan (1984), Social Dynamics: Models and Methods, Orlando, Academic Press.

United States Arms Control and Development Agency (1986), World Military Expenditures and Arms Transfers, Washington, ACDA.

Wallerstein, Immanuel (1974), The Modern World System, New York, Academic Press.

Wallerstein, Immanuel (1980), The Modern World System, Volume 2, New York, Academic Press.

Wallerstein, Immanuel (1989), The Modern World System, Volume 3, San Diego, Academic Press.

Zimmer, Zachary (1988), The Impact of Arms: A Study of Militarization in the Developing World, Master's thesis, University of Manitoba. 